\title{
Mineralogía y microestructura de la pizarra de techar: comportamiento termoóptico y fisibilidad
}

\author{
Mineralogy and microstructure of roofing slate: thermo-optical \\ behaviour and fissility
}

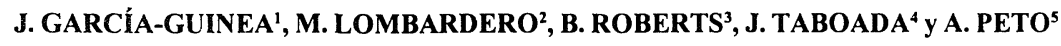

\author{
${ }^{1}$ Museo Nacional de Ciencias Naturales-Madrid (ESPAÑA) \\ ${ }_{2}^{2}$ Instituto Tecnológico Geominero de España-Madrid (ESPAÑA) \\ ${ }^{3}$ Geology Department, Birkbeck College-Londres (REINO UNIDO) \\ ${ }^{4}$ Dpto. Ex. Gráfica en Ingeniería. Univ. Oviedo-Oviedo (ESPAÑA) \\ ${ }^{5}$ Hungarian Academy of Sciences, Instituto de Isótopos-Budapest (HUNGRÍA)
}

Fecha de recepción: 16-1-98

Fecha de aceptación: 2-IV-98

\section{RESUMEN}

La exfoliación de las pizarras depende fundamentalmente de su mineralogía y microestructura, especialmente de la fuerte orientación de los filosilicatos. Esta propiedad permite hendir o abrir las pizarras de techar en láminas muy grandes, delgadas y planas. Se han analizado varias pizarras de techar con diferentes calidades comerciales, correspondientes a diferentes grados de fisibilidad, por radioluminiscencia $(R L)$, termoluminiscencia espectral (TL3D), difracción de rayos $X(D R X)$, microscopia electrónica de barrido (MEB) utilizando el modo backscattered (BSEI) y microsonda electrónica (ME). Las muestras están compuestas por micas blancas, clorita, cuarzo, feldespatos detríticos, ilmenita, pirita, rutilo, apatito y turmalina. Texturalmente, se trata de fenocristales de. cuarzo, feldespatos, interestraficados clorita-mica, moscovita e ilmenita dentro de una matriz microcristalina de micas blancas y clorita con lentejones de cuarzo, todo ello mostrando una fuerte orientación preferencial. Los centros iuminiscentes corresponden a una pequeña banda de emisión espectral alrededor de $400 \mathrm{~nm}$ asociada a pérdidas alcalinas y formación de centros $\left[\mathrm{AlO}_{4}\right]^{\circ}$; un pico a $473 \mathrm{~nm}$ interpretado como un primer escalón termal $\left(150-300^{\circ} \mathrm{C}\right) \mathrm{en}$ un proceso de deshidroxilación no-isotermal caracteristicos de los filosilicatos y un pico a $568 \mathrm{~nm}$ que corresponde con defectos puntuales de $\mathrm{Mn}{ }^{2+}$ en redes de aluminosilicano: Este tipo de estudios sobre fisibilidad pueden ser interesanies porgue Lspaña es el mayor productor de pizarras ae techar (un $87 \%$ de la producción mundial).

\section{SUMMARY}

The mineralogy and microstructure, which affect the slaty cleavage, are linked with the strong preferred orientation of phyllosilicates and this enables the rock to be split into large, thin, flat sheets. Roofing slate samples with different commercial fissilities have been analysed by radioluminescence ( $R L)$, thermoluminescence ( $3 D T L)$, by $X$-ray diffraction (XRD), by scanning electron microscopy (SEM) using the back-scattered mode (BSEI) and by electron microprobe (EMP). They are made up of white micas, chlorite, quartz, detrital feldspars, ilmenite, pyrite, rutile apatite and tourmaline. Texturally, all consist of silt-sized clasts of detrital quartz, feldspars, chlorite-mica stacks, muscovite and ilmenite in a recrystalline, lepidoblastic matrix of white micas and chlorite with quartz lenses, all showing a very strong preferred orientation. The luminescence emission centres are a low broad blue band around the $400 \mathrm{~nm}$ spectra positions linked with alkali losses: and formation of $\left[\mathrm{AlO}_{4}\right]^{\circ}$ defects; a peak at $473 \mathrm{~nm}$ interpreted as a the first thermal step $\left(150-300^{\circ} \mathrm{C}\right)$ of a nonisothermal dehydroxylation of the slate phyllosilicates; and a $568 \mathrm{~nm}$ peak which agrees with $\mathrm{Mn}^{2+}$ point defects in aluminosilicate lattices. The studies on the siaty cleavage could be significant because Spain is the largest producer of roofing slate tiles in the world $187 \%$ of world production: 


\section{INTRODUCCIÓN}

La producción de pizarra de techar representa una parte importante de la minería y cantería española. España produce 600.000 toneladas por año valoradas en unos 40.000 millones de pesetas en 1997 (1). La producción de pizarras es una antigua tradición española. En 1952 funcionaban artesanalmente varias pequeñas canteras en Carballeda (Orense), lo cual ha derivado posteriormente en la mayor zona de producción de pizarras del mundo. A comienzo de los sesenta, algunas canteras empezaron a mecanizarse y en 1969 se fundó la primera gran empresa comercial de producción pizarrera. En los setenta, la industria de la pizarra se expandió muy rápidamente y en los ochenta hubo un desarrollo masivo de toda la zona. Se produjo un gran incremento de las exportaciones, pero ello generó un gran aumento de los recortes de deshecho y los costes de producción, sobre todo en aquellas situadas en las laderas de las montañas (2). Las empresas de cantería se lanzaron a explorar nuevas zonas y nuevos cuerpos de pizarras favorables. Recientemente, en los noventa, la industria pizarrera ha adquirido nuevas técnicas de extracción, utilizando hilo de diamante y sierras de diamante en cantera, el desarrollo de corte de rachones (bloques) y la utilización de mecanismos automáticos de exfoliación segun la pizarrosidad. Estos métodos modernos han aumentado el rendimiento desde un $2 \%$ hasta casi un $13 \%$ de pizarra útil.

Las pizarras de techar son rocas de grano fino con una gran fisibilidad (pizarrosidad). Se producen por metamorfismo de bajo grado de formaciones arcillosas. La pizarrosidad se debe a la orientación preferente de los filosilicatos (micas blancas y cloritas) y ello permite hendir la roca en placas de pizarra de techar grandes, delgadas, ligeras y planas. El grado de fisibilidad depende del diámetro de los elementos no planares de la roca, mayoritariamente cuarzo, otros elementos detríticos y los apilamientos de interestratificados clorita-micas $(3,4)$. La existencia de un buen yacimiento de pizarra de techar precisa de la conjunción de varios factores geológicos favorables, como una composición mineral, textura y estructura adecuadas y esto raras veces ocurre. Se define un litotecto de pizarra de techar como una formación geológica con las características específicas de estas pizarras, precisándose, además, que las capas tengan un espesor mínimo de varios metros y que algunos otros parámetros exigidos por la explotación minera sean favorables.

La pizarra de techar está comúnmente formada por micas blancas (illita-moscovita fengítica, \pm micas sódico-potásicas, \pm paragonita), clorita y cuarzo, pudiendo contener pequeñas cantidades de cloritoide, albita, feldespato potásico, calcita, sulfuros de hierro,

\section{INTRODUCTION}

Roofing slate production is an important part of the Spanish quarrying and mining industry. Spain produces 600,000 tonnes/year, this amount was responsible for profits of $£ 160$ million in 1997 (1). Slate production is an old tradition in Spain. In 1952 several smail hand-operated quarries in Carballeda (Orense) opened which led to what is now the biggest slate producing area in the world. At the beginning of the sixties some old quarries, where everything had been done by hand, started using machinery. In 1969 the first big commercial slate company of Spain was founded. In the 70s the slate industry expanded greatly, exporting ever larger quantities. In the 80 s a massive development occurred. There was a huge increase in exports, but, with the increase of waste products, the quarries became more expensive to run especially as the majority of quarries are cut into steep slopes (2). Quarrying companies began exploration to locate and assess new slate bodies. Most recently, in the 90s, the slate industry has acquired new techniques using diamond wire and diamond saw cutting methods, the development of block sawing and the use of automatic devices to split blocks along the slaty cleavage into roofing slates. These modern methods have increased the yield from $2 \%$ to about $13 \%$ of useful slate.

Roofing slates are very fine-grained rocks having a penetrative (or slaty) cleavage. They develop mostly from muddy sediments during very low grade metamorphism. Slaty cleavage is due to the strong preferred orientation of phyllosilicates (white micas and chlorites) and this enables the rock to be split into large, thin, flat sheets. The fissility is controlled by the diameter of detrital, silt-sized grains, mostly of quartz, but also by chlorite-mica stacks $(3,4)$. A coincidence of geological factors, such as suitable mineral composition, texture and structure is necessary for a slate formation outcrop to be exploitable for roofing slate. This coincidence is only seldom realised. A slate lithotect can be defined as a lithological facies, the characteristics of which are those of roofing slate deposits. It is required to be at least several metres in thickness.

Slate is a metapelite, commonly composed mainly of white micas (usually phengitic illite-muscovite, \pm $\mathrm{Na}, \mathrm{K}$-mica, \pm paragonite), chlorite and quartz together with lesser amounts of one or more of chloritoid, albite, K-feldspar, calcite, iron sulphides, graphitic 
materia grafítica, turmalina, rutilo, zircón y apatito. Las pizarras de techar que contienen demasiada cantidad de sulfuros de hierro (pirita, marcasita, pirrotina) y carbonatos no sirven para uso ornamental por la rápida meteorización de estos compuestos (5). La hidroxidación bioquímica de la marcasita y pirrotina es muy rápida y produce grandes volúmenes de ácido. La pirita es más resistente, alterándose sólo en ambientes más ácidos, como en zonas de lluvia ácida, zonas urbanas o en combinación con pirrotina cuya alteración genera $\mathrm{pH}$ muy ácidos. Los carbonatos se descomponen muy rápidamente en estos ambientes ácidos y producen manchas blancas en la pizarra.

Las mejores pizarras de techar se obtienen de formaciones geológicas que han sufrido metamorfismo regional de bajo grado en la facies de esquistos verdes, lo cual coincide con los valores de cristalinidad de illita, o índices de Kubler (6) que presentan, entre 0,15 y 0,25 . Sin embargo, si existen paragonita y/o micas sódico-potásicas se miden valores Kubler mas altos, que indican, aparentemente, metamorfismo de grado mas bajo $(7,8)$. El tamaño de grano de las pizarras de techar suele ser muy pequeño, por debajo de los $75 \mu \mathrm{m}$, siendo en las de mejor calidad $<30 \mu \mathrm{m}$. La homogeneidad del tamaño de grano es un factor crítico. La textura de la pizarra de techar debe ser lepidoblástica con una pizarrosidad continua $(9,10,11)$. En relación con la deformación tectónica experimentada, la pizarrosidad se forma en el plano $\mathrm{XY}$ del elipsoide de compresión y tiene una relación axial-planar asociada a los pliegues tectónicos (12). Así pues, la penetratividad de la exfoliación de pizarrosidad depende del grado de orientación preferencial, del tamaño y homogeneidad de grano, y de la deformación tectónica.

Algunas pizarras desarrollan una lineación penetrativa paralela a la dirección $Y$ del elipsoide de deformación que puede observarse en las superficies de exfoliación. A esto se le denomina "hilo" en España, "grain" por los canteros británicos, "longrain" en las Ardennes y "down-dip-lineation" en Hobbs et al. (13). Le Corre (14) lo describe en pizarras del oeste de Francia y desarrolla un método óptico para determinar su dirección. Esta estructura, que es diferente de la lineación no penetrativa producida por las intersecciones estratificación-exfoliación, es muy importante para seleccionar la dirección preferente del aserrado de bloques. Existe una potencial confusión porque los canteros do USA denominan "grain" a otro tipo de lineación (15).

La estratificación y las laminaciones $\left(S_{0}\right)$ debidas a cambios en el tamaño y composición de grano, nomalmente producen retracción de la exfoliación e incluso roturas on su contimidad $y$, consecuentemente. matter, tourmaline, rutile, zircon and apatite. Roofing slates are $22-25 \%$ quartz, 40-60\% white micas and 15-20\% chlorite. Chloritoid may sometimes reach up to 10\%. Slates which contain large amounts of iron sulphides (pyrite, marcasite, pyrrothite) and carbonates are not suitable for ornamental uses. This is due to the rapid weathering of these minerals (5). The biochemical hydroxidation of marcasite and pyrrhotite is very fast and accompanied by volume changes and acid generation. Pyrite is more resistant, only decaying in acid environments, i.e. in urban areas of acid rain or peat cover, or in association with pyrrhotite which breakdown produces very low $\mathrm{pH}$. Carbonates are rapidly leached in acid environments and cause white spots on the slate.

The best roofing slates have been obtained from formations which have experienced low grade regional metamorphism under low greenschist facies conditions, i.e. the chlorite zone for metapelites $\left(T=300-400^{\circ} \mathrm{C} ; P=2-3 \mathrm{~kb}\right)$. Most have white mica (illite) crystallinity values, or Kubler indices (6), of 0.15-0.25 and are therefore epizonal rather than anchizonal. The presence of paragonite and/or $\mathrm{Na}, \mathrm{K}$-mica, however, leads to speciously high values and therefore to indication of apparently lower grades $(7,8)$. Texture is an important factor in slate fissility. The grain size of roofing slates is very small, being generally under $75 \mu \mathrm{m}$ and $<30 \mu \mathrm{m}$ the slates of good quality. Grain size homogeneity is a critical factor. Roofing slate texture must be lepidoblastic with continuous slaty cleavage $(9,10,11)$. In accordance with the tectonic deformation supported, the slaty cleavage forms in the $X-Y$ plane of the strain ellipsoid (12). In turn, the penetrative fabric of the slate fissility is dependent on the degree of preferred orientation, grain size and homogeneity.

Some slates develop a penetrative lineation, parallel to the $X$-direction of the strain ellipsoid, which is seen on the cleavage surfaces. This is termed "hilo" in Spain, "grain" by British quarrymen, "longrain" in the Ardennes and "down-dip-lineation" by Hobbs et al. (13). Le Corre (14) described it from slates in W. France and developed an optical method to determine its direction. It strongly influences the preferrea direction of saw cut in producing blocks. It is distinct from the non-penetrative lineation produced by bedding/cleavage intersections, though this lineation too usually influences the direction of saw cut in block production. Potential for confusion exists because U.S. quarrymen refer to this non-penetrative lineation as "grain" (15).

Bedding and lamination traces $\left(S_{0}\right)$, due to changes in grain size and composition, usually result in cleavage refraction or even in breaks in the continuity of the cleavage and make exploiting the slate difficult. This may 
dificultan la explotación del macizo pizarroso. Esto puede representar un serio problema cuando la estratificación y la exfoliación presentan ángulos superiores a los $10^{\circ}$.

La pizarrosidad corresponde con la foliación primaria $\left(S_{1}\right)$, que también es la anisotropía que define los potenciales planos de exfoliación. La presencia de foliaciones posteriores que deforman a $\left(\mathrm{S}_{1}\right)$, tales como la foliación de crenulación, causan superficies de exfoliación irregulares que no permiten obtener placas planas. La presencia de pequeños pliegues agudos "(kink-bands)" e inyecciones filonianas, especialmente inyecciones de cuarzo y venas cuarzo-cloríticas, suponen problemas similares. La intersección de la exfoliación y la crenulación con un ángulo bajo puede producir cuñas, en lugar de láminas planoparalelas. Tales cuñas desarrollan una superficie característica, denominada "pizarra quemada" por los canteros.

La gran mayoría de las formaciones geológicas de pizarra no contienen macizos rocosos explotables debido a los estrictos requerimientos de condiciones necesarias que deben cumplir como mineralogía, grado metamórfico, textura, espesor de banco y tipo de discontinuidades del macizo rocoso.

\section{MUESTRAS Y MÉTODOS}

El muestreo de pizarras de techar se realizó en la comarca de Valdeorras (Orense, España) donde están los mayores litotectos de pizarra del Mundo. Entre las pizarras de mejor calidad comercial se tomaron muestras con tres grados de fisibilidad: $\mathrm{H}=$ Muy alta, $\mathrm{M}=$-media y $\mathrm{L}=\mathrm{Baja}$. La muestra $\mathrm{H}$ procede de un horizonte alto de la formación Pizarras de Luarca de edad geológica Llandeilo (Ordovícico). Las muestras $\mathrm{M}$ y $\mathrm{L}$ proceden de diferentes horizontes de la formación geológica Casaio de edad Caradoc (Ordovícico). La muestra $\mathrm{L}$ procede del flanco invertido de un pligue geologico a mesoescala.

Las pizarras fueron estudiadas por óptica de polarización, por difracción de rayos $\mathrm{X}(\mathrm{DRX})$, microscopía electrónica de barrido (MEB) utilizando el modo back-scattered (BSEI) y microsonda electrónica (ME), por radioluminiscencia $(\mathrm{RL})$ y por termoluminiscencia espectral (TL3D) desde $200 \mathrm{~nm}$ hasta $800 \mathrm{~nm}$ y desde temperatura ambiente hasta $400^{\circ} \mathrm{C}$ (longitud de onda temperatura - intensidad fotónica de emisión). Se prepararon secciones delgado-pulidas para observación petrográfica y análisis de microsonda y secciones delgadas para microscopía electrónica de transmisión. Estas secciones delgadas fueron cortadas perpendicularmente a la estratificación y a la exfoliación para conseguir orientaciones óptimas para observar por become more of a problem when the bedding and cleavage angles of intersection are greater than $10^{\circ}$.

The slaty cleavage is often the primary foliation ( $\left.S_{\nu}\right)$ which is also the anisotropy that defines the planes of potential splitting. The presence of younger foliations which deform $S_{i}$, such as crenulation cleavage $\left(S_{1}\right)$ causes, at best, irregular surfaces of potential splitting which do not allow flat sheets to be produced. The presence of kink-bands and mineral veins, especially quartz veins and quartz-chlorite veins, introduces similar problems. Low angles between exfoliation and crenulation may lead to low-angled wedges of siate instead of parallel-faced sheets. Such wedges develop a characteristic surface named "burnt slate" for the quarrymen.

The great majority of the geological formations of slate are not exploitable massifs of rock because a narrow set of limitations as mineralogy, metamorphic grade, texture, layer thickness and discontinuities of the rock massif are necessary.

\section{SAMPLES AND METHODS}

Selected roofing slate samples were collected from Valdeorras (Orense, Spain) where are the best slate lithotects of the World. Different degrees of development of good fissility, have been studied ( $H=$ high, $M=$ medium and $L=$ low commercial fissility). Sample $H$ is from an horizon high in the Luarca Formation and is of Llanvirn-Llandeilo (Ordovician) age. Samples $M$ and $L$ are from different horizons of the Casaio Formation of Caradoc (Ordovician) age. Sample $L$ is from the inverted limb of a meso-scale fold.

Slates were studied optically, by X-ray diffraction (XRD), by scanning electron microscopy using the back-scattered mode (BSEI), by electron microprobe $(E M P)$, by radioluminescence $(R L)$ and spectra thermoluminescence (3DTL) from $200 \mathrm{~nm}$ to $800 \mathrm{~nm}$ and from $R T$ to $400{ }^{\circ} \mathrm{C}$ (wavelength vs temperature vs thermoluminescent photonic intensity). Regular polished thin sections were prepared for petrographic observation and EMP analysis, and stickywax-mounted thin sections for TEM specimens. Thin sections were cut perpendicular to both bedding and cleavage to obtain optimum orientation for SEM observations of textural relationships. Following SEM study using back-scattered electron (BSE) imaging and X-ray 
MEB las relaciones texturales. Los estudios por MEB y energias dispersivas de rayos $\mathrm{X}$ (EDS) fueron realizados segun el método descrito por Li et al. (3) en un microscopio electrónico de transmisión y de barrido Philips CM12 (STEM) acoplado con un detector Kevex Quantum y un sistema informático. El STEM fue utilizado con un voltaje de aceleración de $120 \mathrm{kV}$ y un amperaje de aproximadamente de $10 \mathrm{~mA}$. Las composiciones químicas de los apilamientos de interestratificados de clorita y de mica fueron también determinados usando una microsonda Cameca CAMEBAX a $12 \mathrm{kV}$ y un voltaje de aceleración de $10 \mathrm{nA}$.

Los difractogramas de rayos fueron obtenidos con polvo molido de la muestra de roca total y en placas cortadas según diferentes orientaciones espaciales. Se utilizó un difractómetro Philips con monocromador de grafito y radiación $\mathrm{CuK} \alpha$ para definir los minerales principales.

Las medidas de termoluminiscencia espectral fueron realizadas en el espectrómetro de alta sensibilidad de la Universidad de Sussex (16). Las emisiones fotónicas de la muestra fueron detectadas con un par de espectrómetros multicanal con filtros, uno en la región azul-ultravioleta $(200 \mathrm{~nm}-450 \mathrm{~nm})$ y otro en la región azul-verde-rojo (400 nm-800 nm) del espectro electromagnético. Las emisiones fueron registradas en el rango espectral $200 \mathrm{~nm}-800 \mathrm{~nm}$ con una resolución de $5 \mathrm{~nm}$ para 100 puntos del espectro, $3 \mathrm{~nm}$ para 200 puntos del espectro y todas las señales fueron corregidas segun la respuesta espectral del sistema. El tubo de rayos $\mathrm{X}$ utilizado para la excitación de las muestras fue un Philips MG MCN 101 con una corriente de $5 \mathrm{~mA}$ y un voltaje de $5 \mathrm{kV}$ dando una dosis de irradiación de $10 \mathrm{~Gy} / \mathrm{min}^{-1}$ a la muestra. Los espectros de RL fueron recogidos durante la excitación de la muestra a $40 \mathrm{kVp}$ con una corriente de tubo de 15 $\mathrm{mA}$ que proporcionaba $10 \mathrm{~Gy} /$ minuto a la muestra. Siempre se utilizaron fragmentos nuevos de muestra porque los espectros son diferentes en muestras ya irradiadas o calentadas.

\section{LUMINISCENCIA Y COMPORTAMIENTO TERMO-ÓPTICO.}

Las medidas de termoluminiscencia espectral (Figuras 1A y B) y radioluminiscencia (Figura 1C) de pizarras irradiadas (300 Gy de rayos X) muestran un pico dominante a $568 \mathrm{~nm}$ que ha sido repetidamente atribuido a la presencia de iones $\mathrm{Mn}^{2+}$ en posiciones de $\mathrm{Ca}$, por ejemplo, en las redes aluminosilicatadas de la plagioclasa (17). Ambos estudios (TL3D y RL) muestran los mismos centros emisores de luz:

a) Una pequeña banda ancha alrededor de los $400 \mathrm{~nm}$ que puede estar asociada con la sensibilización termal energy dispersive spectral (EDS) analysis, ion-milled specimens were prepared following the method described in Li et al. (3) on a Philips CM12 scanning transmission electron microscope (STEM) fitted with a Kevex Quantum solid-state detector and computer system. The STEM was operated at an accelerating voltage of $120 \mathrm{kV}$ and a beam current of $\sim 10 \mathrm{~mA}$. Chemical compositions of the coarse chlorite and mica in stacks were also determined using a Cameca CAMEBAX electron microprobe operated at $12 \mathrm{kV}$ accelerating voltage and $10 \mathrm{nA}$ beam current.

$X R D$ data were obtained for the powdered bulk rock sample and rock slices, using a Philips automated diffractometer with graphite monochromator and $C u K \alpha$ radiation to define the principal minerals.

The 3DTL measurements were made using the TL spectrometer of the University of Sussex (16). Photon emission from the sample was detected via a pair of spectrometers, with gratings blazed for the UV-blue (200 nm-450 nm) and blue-green-red (400 nm-800 nm) parts of the spectrum, and a pair of position-sensitive photomultiplier tubes. Signals were recorded over the wavelength range $200 \mathrm{~nm}-800 \mathrm{~nm}$, with a resolution of $5 \mathrm{~nm}$ for 100 point spectra, and $3 \mathrm{~nm}$ for 200 point spectra, and all signals were corrected for the spectral response of the system. The X-ray unit tubes was a Phillips MG MCN 101 -ray tube with a current of $5 \mathrm{~mA}$ and a voltage of $5 \mathrm{kV}$ delivering $a$

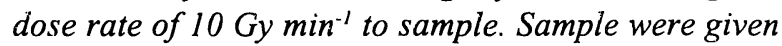
a total dose of $50 \mathrm{~Gy}$, later the spectra TL were recorded while samples were heated to from $R T$ to $400^{\circ} \mathrm{C}$ at $5^{\circ} \mathrm{C} \mathrm{s}^{-1}$. RL spectra were taken during excitation with a $40 \mathrm{kVp} X$-rays with a tube current of $15 \mathrm{~mA}$ which delivers some $10 \mathrm{~Gy} /$ minute at the sample. Fresh samples were normally used for each set of measurements because the emission spectra change after irradiation and heating cycles.

\section{THERMO-OPTICAL BEHAVIOUR AND LUMINESCENCE MEASUREMENTS}

The measurements of the spectra thermoluminescence (Figures $1 A$ and $B$ ) and radioluminescence (Figure IC) of irradiated slate (300 Gy of X-rays) display a dominant emission peak at $568 \mathrm{~nm}$, it has been shown to be caused by $\mathrm{Mn}^{2+}$ ions in Ca sites, e.g. in aluminosilicate lattices of plagioclase (17). Both the $R L$ and spectra TL shows the same emissions centres:

a) A small broad blue band around the $400 \mathrm{~nm}$ spectra positions which can be connected with a thermal 


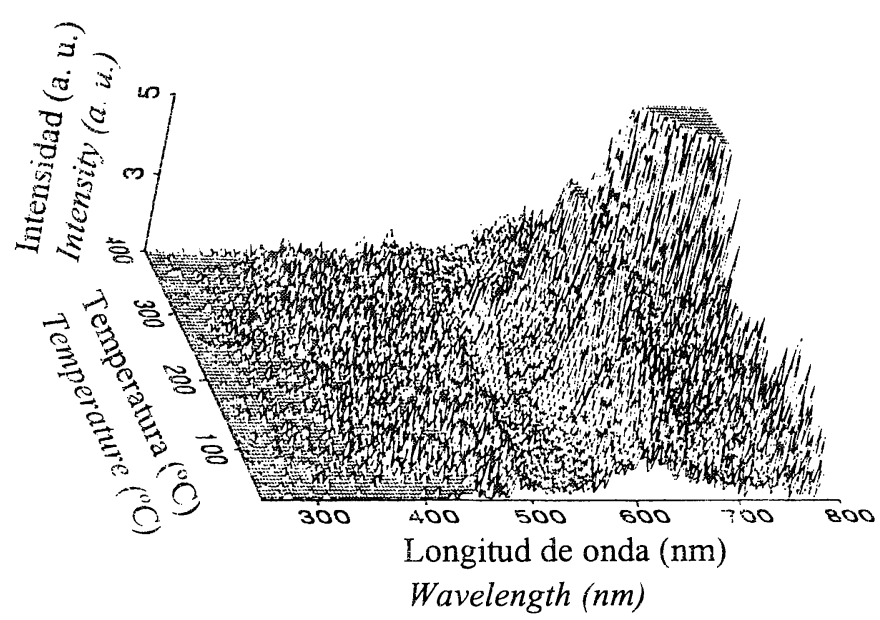

A

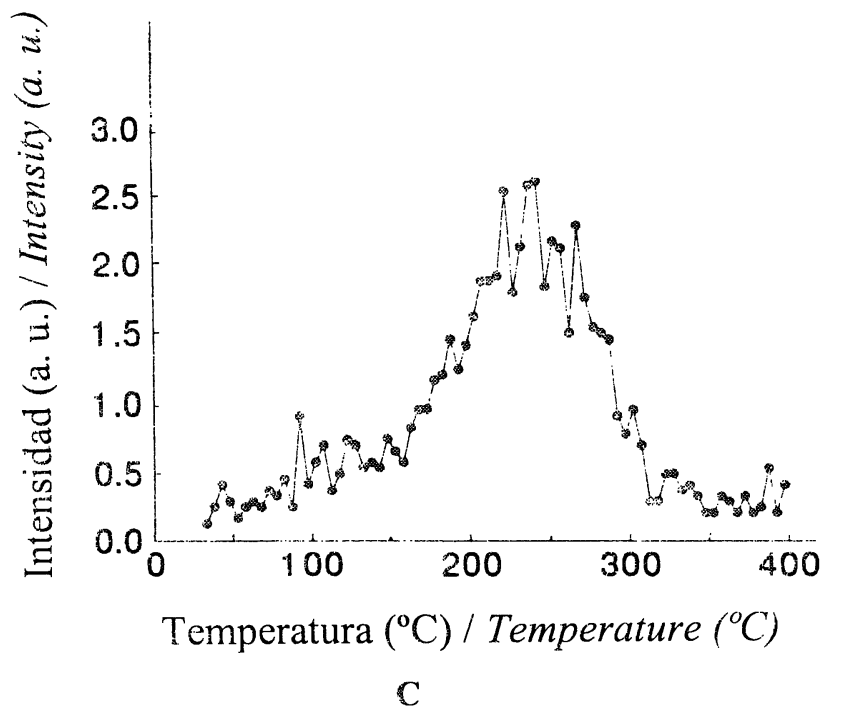

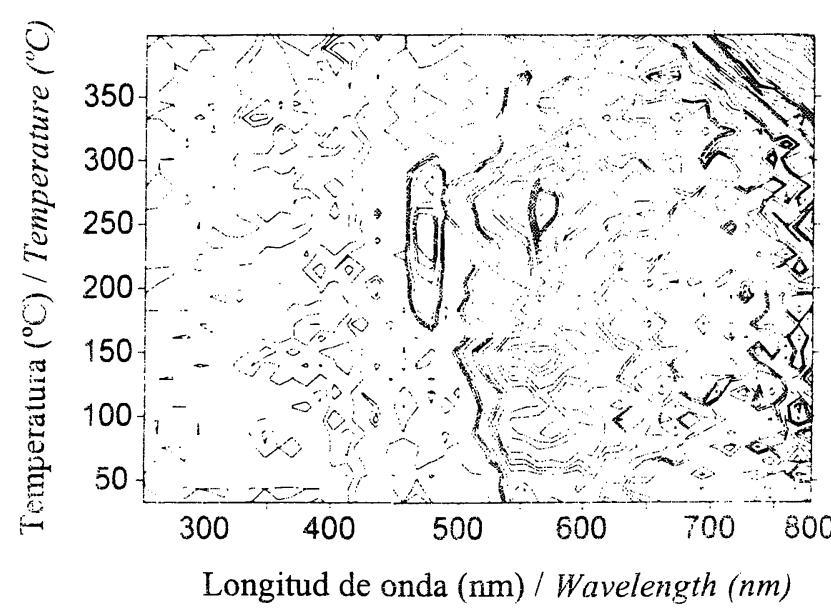

B

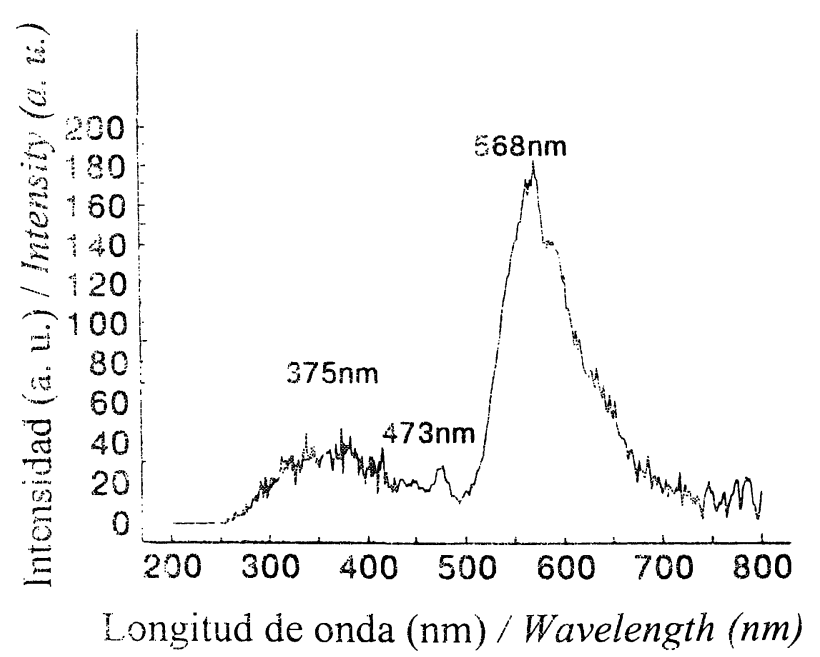

D

Fig. 1.-A) Proyección isométrica de la intensidad de la termoluminiscencia frente a temperaturas y longitudes de onda de una pizarra de techar (H) irradiada (300 Gy de rayos X) de Barco de Valdeorras (Orense, España). B) Proyección basal de las mismas medidas de termoluminiscencia mostrando las posiciones espectrales de los picos $(473 \mathrm{~nm}$ y $568 \mathrm{~nm}$ ). C) Una sección de temperatura tomada a una posición espectrai fija $(473 \mathrm{~nm})$ mostrando la forma de de la curva de termoluminiscencia. D) Registro de la curva de radioluminiscencia, intensidades fotónicas frente a longitudes de onda tomada a $40 \mathrm{~kW} / 15 \mathrm{~mA}(10 \mathrm{~Gy} / \mathrm{min}$.), los picos muestran las mismas posiciones espectrales que los análisis de TL.3D (473 nm y $568 \mathrm{~nm}$ ).

Fig. I.- A) An isometric plot of the thermoluminescence intensity versus wavelength versus temperature for a sample of an irradiated sample (300 (iy of $X$-ray) of roofing slate (H) from Barco de Valdeorras (Orense, Spain). B) A contour plot of the same measurements showing the position of the spectra peaks (at $473 \mathrm{~nm}$ and $568 \mathrm{~nm}$ ). C) A temperature slice taken for the 473nm spectrum position displaying the shape of the glow curve. D) A plot of the radioluminescence intensity versus wavelength at $40 \mathrm{~kW} / 15 \mathrm{~mA}(10 \mathrm{~Gy} / \mathrm{min}$.), it has the same peaks as the 3DTL (473 nm and $568 \mathrm{~nm})$ analysis.

de las redes de aluminosilicato debido a pérdidas de álcalis que consecuentemente producen centros $\left[\mathrm{AlO}_{4}\right]^{\circ}$ (18).

b) La forma plana de los picos de TL3D a $473 \mathrm{~nm}$ y la forma irregular de la curva de termoluminiscencia (Figura 1D) parecen indicar un proceso de continuo de formación y destrucción de trampas de luminiscencia (defectos cristalinos) durante el análisis termal. Este efecto puede estar asociado con el primer escalón termal $\left(150-300^{\circ} \mathrm{C}\right)$ característico de la deshidroxilación isotermal de los filosilicatos. sensitization of aluminosilicate lattices caused by alkali losses and consequently a formation of $\left[\mathrm{AlO}_{4}\right]^{\circ}$ defects (18).

b) The flat shape of the $473 \mathrm{~nm} 3 \mathrm{DTL}$ peak and the irreguiar TL glow curve (Figure iD) suggesi a continuous retrapping process (formation-destruction of luminescence traps) during the thermal analysis, this effect could be linked with the first thermal step (150-300 0 of a non-isothermal dehydroxylation of slate phyllosilicates. 
c) La posición espectral del pico $568 \mathrm{~nm}$ y la cinética de primer orden corresponden con defectos puntuales, como $\mathrm{Mn}^{2+}$ en la estructura cristalina. Este ión es el activador de luminiscencia mas activo en las redes de feldespatos y siempre emite desde una posición espectral cercana a los $560 \mathrm{~nm}$ (19).

d) Estos ejemplares seleccionados de pizarras de techar no muestran las emisiones a 700-800 nm que normalmente corresponden a centros de $\mathrm{Fe}^{3+}$ en redes de aluminosilicatos y dependen de los contenidos de hierro. La presencia de sulfuros de hierro (pirita, marcasita, pirrotina) no está permitida en usos ornamentales de la pizarra.

La baja intensidad de la totalidad del espectro termoluminiscente concuerda con la presencia de iones metálicos en las redes cristalinas y colores oscuros de las muestras. En conclusión, la medidas termoópticas (TL3D) y la radioluminiscencia, evidencian procesos de autodifusión iónica y deshidroxilaciones no isotermales en los filosilicatos de la pizarra (curvas con multiorden cinético y formas planas de las emisiones TL3D) y defectos cristalinos puntuales debidos a iones metálicos que siguen los modelos de la teoría de conducción de valencia.

Un buen conocimiento de la deshidroxilación de los filosilicatos y los mecanismos de pérdidas de agua en tratamientos isotermales y no isotermales de las pizarras de techar podría ayudar a explicar el hecho de que los bloques de pizarra secos tienen peor fisibilidad que los bloques mantenidos bajo del agua. Además de los análisis mineralógicos, texturales y estructurales, este estudio termoóptico podría representar un primer paso hacia el principal objetivo comercial de la pizarra de techar, que es poder hendir los bloques en finas láminas.

\section{OBSERVACIONES ÓPTICAS Y MINERALOGÍA}

Mineralógicamente, todas las muestras de pizarra estudiadas, contienen, en orden de importancia, los siguientes minerales: micas blancas, clorita, cuarzo, feldespatos detríticos, ilmenita, pirita, rutilo, apatito y turmalina. La muestra $\mathrm{H}$ es la única que contiene cloritoide y una pequeña cantidad de paragonita además de micas fengíticas sódico-potásicas $2 \mathrm{M}_{1}$ Texturalmente, todas las muestras están compuestas de partículas tamaño limo de cuarzo detrítico, feldespatos, apilamientos clorita-mica, moscovita e ilmenita en una matriz lepidoblástica recristalizada de micas blancas, micas, clorita y tentes de cuarzo, todo ello mostrando una fuerte orientación preferencial. La turmalina, el rutilo, la pirita y el apatito están c) The spectra position of the $568 \mathrm{~nm}$ peak and the kinetics of first order corresponds with point defects in the structure as $\mathrm{Mn}^{2+}$. This ion is the most efficient extrinsic luminescence activator in feldspar lattices and always emits from a spectra position around 560 nm (19).

d) These selected roofing slates samples do not display 700-780 $\mathrm{nm}$ emissions which normally correspond with $\mathrm{Fe}^{3+}$ sites in aluminosilicates lattices in accordance with its low iron contents. The presence of iron sulphides (pyrite, marcasite, pyrrothite) is not allowed for ornamental uses.

The low intensity of the whole photonic emissions also agree with the presence of metallic ions in the lattice and the dark colour of the samples. In short, the thermo-optical measurements (TL and RL) in slates can make visible ionic self diffusion processes and nonisothermal dehydroxylations in phyllosilicates (multiorder kinetic glow curves and flat shapes of 3DTL emissions) and metallic point defects which follows the conduction band theory models.

A well understanding of the phyllosilicate dehydroxylation and water loss mechanisms in isothermal and non-isothermal treatments of roofing slates could to help to known why dry slates have a poorer fissility than wet ones. In addition to the textural, mineralogical and structural analyses, this thermo-optical study could be a first step to cope with the main commercial target which is to split the slate blocks into thin and flat sheets.

\section{OPTICAL OBSERVATIONS AND MINERALOGY}

Mineralogically, all samples consist, in order of decreasing abundance, of white micas, chlorite, quartz, detrital feldspars, ilmenite, pyrite, rutile, apatite and tourmaline. Sample $H$ is unique in containing chloritoid and discrete paragonite in addition to phengitic $2 M_{3} \mathrm{Na} / \mathrm{K}$-mica. Texturally, all consist of silt-sized clasts of detrital quartz, feldspars, chloritemica stacks, muscovite and ilmenite in a recrystalline lepidoblastic matrix of white micas, chlorite and quartz lenses, all showing a very strong preferred orientation. Tourmaline, rutile, pyrite and apatite are dispersed through the matrix and frequently also show 
dispersos en la matriz y frecuentemente tambien muestran orientación cristalográfica preferencial.

Muestra de pizarra H (Figuras 2A y B).- Contiene sólo escasos apilamientos de clorita-mica dispersos en una matriz de filosilicatos de grano muy fino altamente orientados, que definen los planos $S_{1}$ Los contactos intergranulares muestran relaciones de deformación. Los apilamientos están fuertemente deformados con relaciones axiales de 1:4 a 1:5. Tienen tamaños de hasta $60 \times 250 \mu \mathrm{m}$, pero normalmente son de $20 \times 100 \mu \mathrm{m}$. Los granos de cuarzo detrítico también están ampliamente dispersos, fuertemente deformados y, normalmente, tienen un tamaño de $10 \times 30 \mu \mathrm{m}$. Los granos de feldespatos potásicos tienen tamaños similares y se presentan sólo ocasionalmente. El tamaño del cuarzo y feldespato más común es el de limo, mientras que los apilamientos de clorita-mica alcanzan tamaños de arena muy fina. Tambien aparecen microporfiroblastos rectangulares de cloritoide orientados según el plano $\mathrm{S}_{1}$ alcanzado tamaños de hasta $150 \times 15 \mu \mathrm{m}$. Ocasionalmente, aparecen en secciones transversales con tamaños de hasta $100 \times 25 \mu \mathrm{m}$, en estos casos desarrollan contactos de presión. La fracción $<2 \mu \mathrm{m}$ fue identificada por DRX y en orden de abundancia decreciente es mica sódico-potásica $2 \mathrm{M}_{1}$, clorita, paragonita, cuarzo, albita y rutilo. El cloritoide y el feldespato potásico no se dectectan en esta fracción. El tamaño y la frecuencia de los apilamientos mica-clorita y los microporfiroblastos no orientados de cloritoide influyen sobre el espesor de las placas que se pueden obtener de esta pizarra. La muestra tiene un índice de Kubler de $0,29 \mathrm{D}^{\circ} 2 \mathrm{~J}$, pero este valor está exagerado por la presencia de mica sódico-potásica y una discreta cantidad de paragonita. El parámetro de celdilla $b$ de las micas blancas, que es $9,01 \AA$, apunta hacia unas facies metamórficas de baja presión.

Muestra de pizarra M (Figuras 2C y D).

Originariamente fue una roca arcillosa con algunas laminaciones de limos y arenas de grano muy fino. Tales laminaciones, fueron transpuestas durante la deformación que dio origen a $S_{1}, y$, frecuentemente, aparecen como lentejones de hasta $400 \mu \mathrm{m}$ de espesor. Los apilamientos de clórita-mica aparecen en ambas partes de la roca: en la metapelita procedente de roca arcillosa y en las laminaciones procedentes de limos. A menudo ofrecen secciones subrectangulares y tamaños aproximados de $150 \times 150 \mu \mathrm{m}$. La deformación $\mathrm{S}_{\text {, ha }}$ generado sombras de presión de cuarzo y filosilicatos de granos muy finos produciendo microestructuras que alcanzan los $150 \times 600 \mu \mathrm{m}$. El cuarzo detrítico habitualmente está aplastado según el plano de exfoliación, pero existen algunos granos cruzados en formas de lentes, siendo de un tamaño aproximado de $50 \times 100 \mu \mathrm{m}$. Esporádicamente se presentan granos crystallographic or grain-dimensional preferred orientation

Sample $H$ (Figure 2, A and B) contains only a few, widely dispersed chlorite-mica stacks against which the very fine-grained, highly orientated, phyllosilicate-rich matrix, $S_{p}$, shows a contact strain relationship. The stacks are strongly deformed with axial ratios of 4-5. They are up to $60 \times 250, \mathrm{um}$, but commonly are about $20 \times 100 \mu \mathrm{m}$. Detrital quartz grains are also widely dispersed, strongly deformed, and are commonly about $10 \times 30 \mu \mathrm{m}$. Detrital K-feldspar grains of similar size are occasionally present. Thus mean grain size of detrital quartz and $K$-feldspar is medium silt grade whereas chlorite-mica stacks reach very fine sand grade. Rectangular microporphyroblasts of chloritoid mostly lie within the plane of $S$, and range up to $150 \times 15 \mu \mathrm{m}$. Occasionally, however, they are transverse to it, are about $100 \times 25 \mathrm{\mu m}$, and in these cases a contact-strain relationship is developed. The $<2 \mu \mathrm{m}$ fraction (identified by XRD) consists, in order of decreasing abundance, of $2 M_{1} N a / K$-mica, chlorite, paragonite, quartz, albite and rutile. Chloritoid and $K$-feldspar were not detectable in this fraction. It is the size and frequency of the stacks and the transverse chloritoid microporphyroblasts which control the thickness of the thinnest potential cleavage flakes. The sample has a Kubler Index of $0.29 D^{\circ} 2 \mathrm{~J}$ but this value has been inflated by the presence of $\mathrm{Na} / \mathrm{K}$-mica and discrete paragonite. The $b$-cell parameter of white micas is 9.01, suggesting a low pressure metamorphic facies series.

Sample $M$ (Figure 2, C and D) by comparison, was formerly a mudrock with occasional laminae of coarse siltstone to very fine sandstone. The siltstone to very fine sandstone laminae have been transposed during $S_{1}$ development so that they often occur in lens-like masses up to $400 \mathrm{~m}$ thick. Chlorite-mica stacks are present in both the mudrock and the silty laminae. They are often subrectangular in outline and mostly about $150 \times 150 \mu \mathrm{m}$ but the $S$, fabric shows a contact strain relationship against them with the development of pressure shadows, or beards, of quartz and phyllosilicates so that the compound structures reach $150 \times 600 \mu \mathrm{m}$. Detrital quartz is usually flattened in the plane of the cleavage but, within some transposed, lowstrain lenses, quartz is often about $50 \times 100 \mu \mathrm{m}$. Detrital grains of $K$-feldspar and calcite, of comparable size and shape to the quartz, are sporadically present. The matrix of the phyllosilicate-rich bands consists mainly 

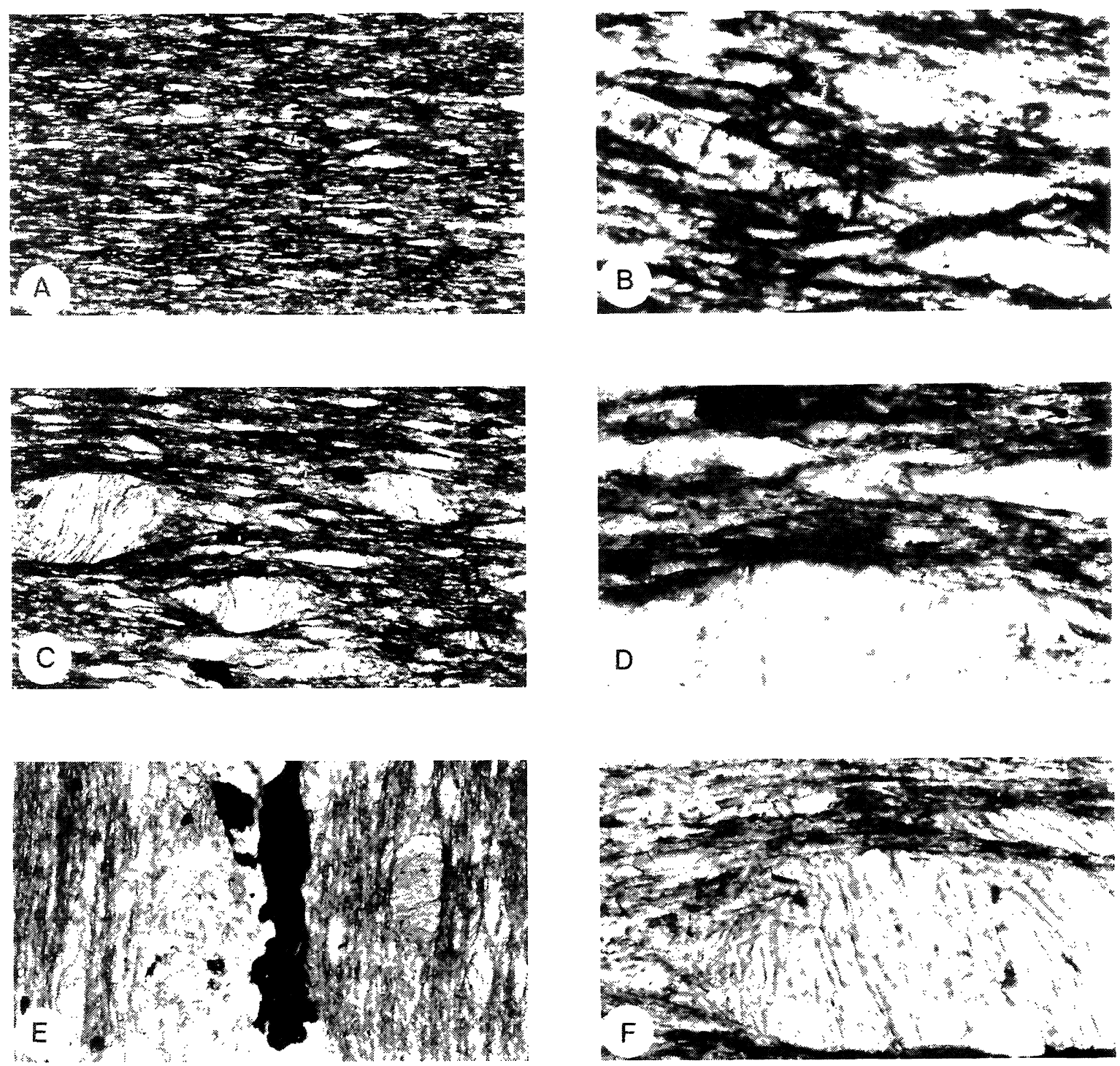

Fig. 2.- Las fotomicrografias de todos los planos han sido tomadas con luz polarizada. A y B) Muestra H. Pizarra de la formación Luarca, dentro del dominio Navia y Alto Sil Domain (Llanvim-Llandeilo, Ordovícico). A) Dimensión larga $=860 \mu \mathrm{m}$. Fuertemente deformada, pequeña, apilamientos clorita-mica y lentes de cuarzo asociadas con granos muy finos, en una matriz de filosilicatos fuertemente orientada. Los microprofiroblastos de cloritoide se emplazan oblicuos a la pizarrosidad. El espaciado de exfoliación está controlado por los apilamientos clorita-mica $(20 \mu \mathrm{m})$. B) Dimensión larga $=220 \mu \mathrm{m}$. Detalle de los microporfiroblastos de cloritoide del centro del campo A, apilamientos mica-clorita deformadas y matriz.C y D) Muestra M. Pizarra de la formación Casaio en el Dominio Truchas (Caradoc, Ordovician). C) Dimensión larga $=860 \mu \mathrm{m}$. Interestratificados de mica-clorita grandes, deformadas y pequeñas lentes de cuarzo contra las que la pizarrosidad desarrolla contactos mecanizados. Espaciado de exfoliación controlado por las pilas de clorita-mica (aproximadamente de $150 \mu \mathrm{m}$ ) y lentes atravesadas de limos de hasta $400 \mu \mathrm{m}$ de espesor (no mostradas). D) Dimensión larga $=220 \mu \mathrm{m}$. Detalle de una parte de un interestratificado clorita-mica y matriz de la parte mas baja, central, del campo C. E y F) Muestra L. Pizarra de la formación Casaio, Dominio de Truchas (Caradoc, Ordovician). E) Dimensión larga $=860 \mu \mathrm{m}$. Área rica en cuarzos atravesados, arena muy fina, $420 \mu$ maproximadamente, alargadas según el plano de fisibilidad; apilamientos deformados de mica-clorita y lentes de cuarzo; matriz rica en filosilicatos. Espaciado de exfoliación controlado por el espesor de los lentejones de arena. F) Dimensión larga $=220 \mu \mathrm{m}$. Detalle del apilamiento mica-clorita (derecha del centro en E) mostrando el desarrollo de cuarzo y filosilicato barbados y un contacto mecanizado con el plano de fisibilidad.

Fig. 2.- (Photomicrographs, all plane-polarised light. A and B) Sample H. Slate, from the Luarca formation in the Navia y Alto Sil Domain (LlanvirnLlandeilo, Ordovician). A) Long dimension $=860 \mu \mathrm{m}$. Strongly deformed, small, chlorite-mica stacks and quartz lenses are set in a very fine grained, strongly orientated phyllosilicate matrix. Microporphyroblast of chloritoid is set oblique to slaty cleavage slightly above centre. Cleavage spacing is controlled by the c. $20 \mu \mathrm{m}$ wide chlorite-mica stacks. B) Long dimension $=220 \mu \mathrm{m}$. Detail of the chloritoid microporphyroblast from the centre of field A, deformed chlorite-mica stacks and matrix. C and D) Sample M. Slate, from the Casaio Formation in the Truchas Domain (Caradoc. Ordovician). C) Long dimension $=860 \mu \mathrm{m}$. Large, deformed, chlorite-mica stacks and smaller quartz lenses against which the slaty cleavage develops a contact-strain relationship. Cleavage spacing is controlled by deformed chlorite-mica stacks (about $150 \mu \mathrm{m}$ wide) and by transposed siltstone lenses up to $400 \mu \mathrm{m}$ thick $($ not shown). D) Long dimension $=220 \mu \mathrm{m}$. Detail of part of the chlorite-mica stack and matrix from the lower, central part of field (.. E and F) Sample L. Slate, from the Casaio Formation in the Truchas Domain (Caradoc, Ordovician). E) Long dimension $=860 \mu \mathrm{m}$. Area of transposed, quartz-rich, very fine sand, $420 \mu \mathrm{m}$ thick; pyrite, elongate in plane of cleavage; deformed chlorite-mica stacks and quartz lenses; phyllosilicate-rich matrix. Cleavage spacing is controlled by the thickness of the sand lenses. F) Long dimension $=220 \mu \mathrm{m}$. Detail of chlorite-mica stack (right of centre in E) showing development of quartz and phyllosilicate-rich beard and a contact-strain relationship to the slaty cleavage) 
detríticos de feldespato potásico y calcita, de tamaños y formas semejantes a los del cuarzo. La matriz de la roca presenta bandas ricas en filosilicatos, básicamente tiene grano muy fino, con los filosilicatos fuertemente orientados y los lentejones de cuarzo aplanados. En orden de abundancia decreciente, la fracción $<2 \mu \mathrm{m}$ está formada por micas potásicas $2 \mathrm{M}_{1}$, clorita, cuarzo, albita y rutilo. No se pudo detectar calcita ni feldespato potásico en esta fracción. La penetratividad de la exfoliación está muy controlada por el tamaño de los elementos desorientados, como cuarzos, lentejones de arenisca de grano fino $\mathrm{y}$, en menor proporción, por los apilamientos de mica-clorita. La muestra tiene un índice de Kubler de $0,24 \mathrm{D}^{\circ} 2 \mathrm{~J}$, y un parámetro de celdilla $b$ de las micas blancas de 9,01. Por lo tanto, se trata de una roca metamórfica de baja presión situada muy cerca del límite entre la anquizona y la epizona.

Muestra de pizarra L (Figuras 2E y F).- Es muy similar a la $\mathrm{M}$. Anteriormente al metamorfismo, también fue una limolita con niveles laminares arcillosos y arenosos. Las láminas de limo son más abundantes y continuas. El ángulo entre la estratificación y la pizarrosidad, es de unos $13^{\circ}$. Las láminas llegan a tener espesores de hasta $500 \mu \mathrm{m}$. Se diferencian en que mientras la mica blanca en los apilamientos de micaclorita es mica potásica fengítica, la mica de la matriz es sódico-potásica $2 \mathrm{M}_{1}$. Su más imperfecta fisibilidad se debe a dos causas: a interrupciones en la pizarrosidad debidas a las laminaciones de limos y al ángulo $\mathrm{S}_{0} / \mathrm{S}_{1}$. La muestra tiene un índice de Kubler de $0,26 \mathrm{D}^{\circ} 2 \mathrm{~J}$, y un parámetro de celdilla $b$ de las micas blancas de 9,01 , por lo tanto se pueden inferir unas condiciones de metamorfismo muy similares a las de la muestra $\mathrm{M}$.

\section{CONCLUSIONES}

Las propiedades estructurales, texturales y mineralógicas de las formaciones de pizarra del noroeste español (comarca de Valdeorras) hacen que se trate del distrito minero productor de pizarra de techar mas importante del mundo. Los principales factores que afectan a la calidad y explotabilidad de las pizarras son: 1) Tamaño de los granos de cuarzo por debajo de los $75 \mu \mathrm{m}, 1$ ) La homogeneidad de la foliación primaria (pizarrosidad) y el ángulo de intersección $S_{0}-S_{1}$ que son probablemente los factores más importantes en la exfoliación de las láminas de pizarra, 3) Grados de muy bajo metamorfismo (índices de Kubler 0,15-0,25 D²J), 4) Ausencia de foliaciones secundarias, 5) Capas de pizarra masiva que superen los 10-12 metros de espesor. 6) Bajos contenidos en sulfuros de hierro.

Considerando que las pizarras secas tienen peor fisibilidad que las húmedas, los métodos of very fine-grained, strongly orientated phyllosilicates and flattened quartz lenses. The $<2 \mu \mathrm{m}$ fraction consists, in order of decreasing abundance, of $2 M_{1} K$-mica, chlorite, quartz, albite and rutile. Neither calcite nor $K$-feldspar were detected in this fraction. The frequency of the cleavage is largely controlled by the thickness of the transposed, quartzrich, very fine sandstone lenses and, to a lesser extent, by the chlorite-mica stacks. The sample has a Kubler Index of 0.24 and $a$ b-cell parameter of white mica of 9.01. It therefore recrystallised as a member of a low pressure metamorphic facies series, close to the boundary between anchi-and epizones.

Sample $L$ (Figure 2, $E$ and $F$ ) is very similar to $M$ and formerly was also an interlaminated mudstone/coarse siltstone. Siltstone laminae are more abundant and continuous and $S_{1}$ intersects $S_{o}$ at about $13^{\circ}$. Laminae are up to 500 um thick. One difference is that whereas the white mica in the chlorite mica stacks is phengitic $2 M_{1} K$-mica, the mica of the matrix is $2 M_{1} N a / K$-mica. The less perfect fissility is due to both the interruption caused by the siltstone laminae and the angle $S_{o} / S_{l}$. The sample has a Kubler Index of 0.26 and $a$ white mica b-cell parameter of 9.01 so that similar conditions of metamorphism to Sample $M$ can be inferred.

\section{CONCLUSIONS}

The structural, textural and mineralogical properties of the slate formations of the NW Spain make it the most important district in the world for quarrying/mining roofing slates. The main factors which affect the quality and exploitability of the slates are: 1) Quartz grain size generally below $75 \mu \mathrm{m}$. 2) Homogeneity of the primary foliation (slaty cleavage) and the $S_{0}-S_{1}$ angle of intersection are probably the most important factors in the splitting of the slate. 3) Very low metamorphic grade (Kubler index of 0.15-0.25 $D^{\circ} 2 \mathrm{~J}$ ). 4) Absence of secondary foliations. 5) Beds of massive slate reaching 10-12 $\mathrm{m}$ in thickness. 6) Low content of oxidisable iron sulphides.

Taking into account that dry slates have a poorer fissility than wet ones, thermoluminescence methods 
termoluminiscentes pueden proporcionar interesante información detectándose deshidroxilaciones y pérdidas de agua en los minerales filosilicatados. Ambos, la radioluminiscencia y la termoluminiscencia espectral muestran similares centros emisores de luz: a) Una pequeña banda ancha alrededor de los $400 \mathrm{~nm}$ asociada a pérdidas alcalinas termales con formación de centros luminiscentes de tipo $\left.\left[\mathrm{AlO}_{4}\right]^{\circ}, \mathrm{b}\right)$ Un pico a $473 \mathrm{~nm}$ que podría ser interpretado como un primer escalón termal (150-300 ${ }^{\circ} \mathrm{C}$ ) de una deshidroxilación no isotermal de los filosilicatos de la pizarra, c) La emisión a $568 \mathrm{~nm}$, que es de primer orden cinético concuerda muy bien con la presencia de iones $\mathrm{Mn}^{2+}$ en las redes de los aluminosilicatos.

El estudio mineralógico y textural de las muestras indica que la perfección de la exfoliación de pizarrosidad se incrementa con la disminución del tamaño de los cuarzos detríticos y los apilamientos de mica-clorita. Las pizarras de techar analizadas están formadas por micas, clorita, cuarzo, feldespatos detríticos, ilmenita, pirita, rutilo, apatito y turmalina. Texturalmente son clastos de tamaño limo de cuarzo detrítico, feldespatos, apilamientos mica-clorita, moscovita e ilmenita en una matriz lepidoblástica recristalizada de micas blancas y clorita con lentejones de cuarzo y todo ello mostrando una fuerte orientación preferencial.

\section{AGRADECIMIENTOS}

Agradecemos la inestimable ayuda del Prof. Dr. Townsend por sus orientaciones en los experimentos y por el acceso al espectrómetro de alta sensibilidad de la Universidad de Sussex (UK). A José Carlos Barros Lorenzo, geólogo de la empresa SAMACA, quien realizó el muestreo de las pizarras comerciales y su ubicación geológica. Gracias también a Matthew Harffy por la revisión crítica del manuscrito y a Rafael González Martín por las medidas de difracción de rayos $\mathrm{X}$. El trabajo fue financiado por un proyecto DGICYT (PB95-0108-B). could have enhanced benefits because they allow to detect dehydroxylations and water losses in the phyllosilicate minerals. Both, the radioluminescence and spectra thermoluminescence shows the similar emissions centres: a) a small broad blue band around the $400 \mathrm{~nm}$ spectra positions which can be connected with alkali losses and formation of $\left[\mathrm{AlO}_{4}\right]^{\circ}$ defects, b) The $473 \mathrm{~nm}$ peak could be interpreted as the first thermal step $\left(150-300^{\circ} \mathrm{C}\right)$ of a non-isothermal dehydroxylation of slate phyliosilicates. c) The spectra position of the $568 \mathrm{~nm}$ peak and its first order kinetics agree with $\mathrm{Mn}^{2+}$ point defects in aluminosilicate lattices.

The mineralogical and micro-textural study of the samples indicates that the perfection of the slaty cleavage increases as the proportion and mean grain size of detrital quartz and chlorite-mica stacks decreases. The roofing slates analysed display micas, chlorite, quarts, detrital feldspars, ilmenite, pyrite, rutile apatite and tourmaline. Texturally, all consist of silt-sized clasts of detrital quartz, feldspars, chloritemica stacks, muscovite and ilmenite in a recrystalline, lepidoblastic matrix of white micas and chlorite with quartz lenses, all showing a very strong preferred orientation.

\section{ACKNOWLEDGEMENTS}

We are grateful to Prof. Dr. P.D. Townsend for the guidelines for the experiments and the 3DTL measurements using the high sensitivity thermoluminescence spectrometer of the University of Sussex. Thanks to Matthew Harffy for the critical review of the manuscript, to Rafael González Martin for the X-ray measurements and José Carlos Barros Lorenzo, geologist of the SAMACA Company, for the slates collection and geologica data. The work was supported by a DGICYT project (PB95-0108-B)

\section{BIBLIOGRAFIA}

(1) MARChAN, C.; LOMBARDERO, M.; REGUEIRO, M.; ORTUÑO, G. (1998): "Panorama Minero 1995-1996". Inst. Tecn. Geomin. España. Madrid. (En prensa).

(2) GARCÍA-GUINEA, J.; LOMBARDERO, M.; ROBERTS, B., TABOADA, J. (1997): Spanish roofing slate deposits. Trans. Instn. Min. Metall. (Sect. B: Appl. erath. sci.) 106, B203-B212.

(3) LI, G.; PEACOR, D.R.; MERRIMAN, R.J.; ROBERTS, B.; PLUIJM, B.A. (1994): TEM and AEM constraints on the origin and significance of chlorite-mica stacks in slates: an example from central Wales, U.K. . Jour Struc Geol 16: 1139-1157.

(4) DURNEY, D.W.; KISCH, H.J. (1994): A field classification and intensity scale for first-generation cleavages. Jour Austral Geol Geophys 15: 257-295. 
(5) RUIZ GARCÍA, C. (1977): Aplicaciones del microscopio en relación con la calidad de las pizarras de techar. Bol. Geol. Miner. 88: $1-8$.

(6) KUBLER, B. (1968): Evaluation quantitative du metamorphisme par la cristallinite de l'illite. Bull. Centre Rech.. Pau-SNPA $2,1968,385-397$

(7) FREY, M. (1987): Low temperature metamorphism. Blackie, Glasgow \& London. 351 pp.

(8) ROBERTS, B.; MORRISON C.; HIRONS S. (1990): Low grade metamorphism of the Manx Group: a comparative study of white mica crystallinity techniques. Jour Geol Soc London 147: 271-277.

(9) WOOD, D.S. (1974): Current views of the development of slaty cleavage. Ann Rev Earth Planet Sci 2: 369-401.

(10) POWELL Mc.A. (1979): A morphological classification of rock cleavage. Tectonophys 58: 21-34.

(11) BASTIDA, F. (1981): Las esquistosidad primaria: una síntesis sobre sus características y desarrollo. Trab Geol 11: 35-54.

(12) SIDDANS, A.W.B. (1972): Slaty cleavage- a review of research since 1815. Earth Sci Rev 8: 205-232.

(13) HOBBS B.E.; MEANS, W.D.; WILLIAMS P.F. (1976): An outline of structural geology. Wiley, New York, 571pp.

(14) LE CORRE, C. (1968): La microlinèation des schists ardosieres. Méthode d'étude photométrique. Bull. Soc. Miner. Bretagne (C) I 2: 73-82.

(15) EVANS, N.H.; MARR, J.D. (1988); Geology and the slate industry in the Arvonia District, Buckingham County, Virginia. Virg. Minerals 34: 32-44.

(16) LUFF B.J.; TOWNSEND, P.D. (1992): High sensitivity thermoluminescence spectrometer. Meas. Sci. Technol 3: 65-71.

(17) GEAKE, J.E.; WALKER, G.; TELFER, D.J. (1977): The cause and significance of luminescence in lunar plagioclase. Phil. Trans. R. Soc. Lond. A. 285: 403-408.

(18) MARTINI, M.; PALEARI, A.; SPINOLO, G.; VEDDA, A. (1995:) Role of the [AlO4] ${ }^{\circ}$ in the 380nm thermoluminescence of quartz. Phys. Review B-Condensed Matter 52(1): 138-142.

(19) GARCÍA GUINEA, J.; RENDELL, H.M.; SÁNCHEZ MUÑOZ, L. (1996): Luminescence spectra of alkali feldspars: some relationships between structural features and luminescence emission. Radiation Protection Dosimetry 66 (1-4): 395-398. 